\title{
Adverse Possession in Context of Native Americans
}

\author{
Clifford Fisher ${ }^{1}$ \\ Clinical Professor, Assistant Dean \& Academic, Director for Undergraduate Programs \\ Krannert School of Management, Purdue University
}

Thomas Fisher ${ }^{2}$

Krannert School of Management, Purdue University

\begin{abstract}
This paper discusses the issue of Native American tribes claiming ownership of certain tracts of land, citing their historical ownership of those areas, even though individuals, businesses, and government have claimed ownership to the land. This paper will discuss the doctrine of adverse possession and will demonstrate that many lands occupied by individuals, businesses and government, actually belong to Native American tribes. The doctrine of adverse possession does not apply to the taking of government land, and since Native American tribes are sovereign governments, and thus, lands taken from Native Americans tribes, without treaties, or the sale by deed, are therefore lands still owned by the Native American tribes. After the Native Americans were pushed west of the Mississippi river by treaties with the United States, history suggests that the federal and state governments continued to appropriate their lands through warfare and coercion. As such, a situation has arisen in which arguably the lands that Native American tribes once owned by grants under treaties, may still belong to the tribes; and the residents and business entities on those lands cannot justify their claims of ownership under the law of adverse possession. There have been several lawsuits over the ownership of the areas claimed by Native American tribes resulting in considerable debate over the injustices done to the Native American tribes in past. Despite the efforts of the federal government to compensate for their wrong doings, there has been no clear consensus on what is to be done with the once Native American owned lands. Most of the government's measures to pay damages to the tribes have been in the form of monetary compensations in lieu of lands, or allowance of the Native American tribes to charge rental fees for usage of their land. Several businesses and states have contended that the laws awarding reparations to tribes are stringent and lopsided, thereby harming businesses and giving rise to issues such as maintenance of law and order and loss of tax revenues3.
\end{abstract}

\section{INTRODUCTION}

Adverse Possession is a principle under which a person in possession of land owned by someone else may acquire valid title to the land, so long as state specific legal requirements are met. The legal requirements have evolved over time, and the articulation of those requirements varies between jurisdictions. Hence, the exact elements of an adverse possession claim may be different in each state(see Appendix I).For instance, in Arizona, adverse possession is valid, if the occupation has been in effect for 10 years (or for 5 years inside any city in Arizona), and merely 3 years in case there is color of title4and taxes are paid5.Basically, adverse possession, in order to ripen into title for the possessor, meaning a trespasser, must be:

1. Continuous; this means continual.

2. Hostile to the interests of the true owner - the "adverse" part of adverse possession.

3. Open and notorious -in order to put the true owner on notice that a trespasser is in possession.

4. Actual - so that the true owner has a cause of action for trespass, on which the true owner must act within the number of years defined by the state.

5. Exclusive- no one else is using the property.

${ }^{1}$ Corresponding Author: cdfisher@purdue.edu

${ }^{3}$ http://online.wsj.com/news/articles/SB10001424052702304788404579523661972129936?mg=reno64-wsj

${ }^{4}$ The appearance of having title to personal or real property by some evidence, but in reality there is either no title or a vital defect in the title

${ }^{5}$ The Appendix I discussed this is in more detail, i.e., the adverse possession laws for each state in the USA 


\section{RATionAle BEHIND AdVERSE POSSESSION}

One of the most prominent arguments in favor of adverse possession has been that the evidence of ownership becomes less relevant after a substantial period of time and adverse possession is intended to make the best use of the real property. The establishment of ownership and usage of unclaimed or idle land is encouraged through adverse possession. This is different from the common law doctrine denying title of stolen personal property6to a thief, and prohibiting the thief to pass the title to even a good faith buyer7.An important distinction is that unlike real property, personal property, such as jewelry or work of art does not have a fixed location, and can be concealed easily. Thus, it is more difficult for the true owner to notice possession of personal property by another individual.

It has been argued that adverse possession is sometimes useful or necessary to prevent and rectify the potential or actual defects in real estate titles by discouraging possible litigation over ownership and possession. For example, because of the doctrine of adverse possession, a landowner can be secure in title to his/her land. Otherwise, heirs of any former owner, possessor or lien holder of centuries past could have a legal claim on the property. The principle of adverse possession prevents this, because the law may be used to reward a person who possesses the land of another for a requisite period of time. Thus, the failure of a landowner to exercise and defend his/her property rights for a certain period may result in the permanent loss of the landowner's interest in the property. In economic terms, adverse possession encourages and rewards productive use of land. However, adverse possession cannot be used to claim ownership over land that belongs to the government 8 .

\subsection{Common Defences to Adverse Possession}

A list of defenses to Adverse Possession may be enumerated as follows:

Permissive Use - If the actual owner has granted the claimant permission to use the property, the claim of "adverse possession" cannot be deemed "hostile" and thus fails.

$>$ Public Lands - Government-owned land is exempt from adverse possession.

Insufficient Acts - Although it is conceded that the claimant engaged in some use of the property, it is alleged that these acts were not sufficient to amount to acts suggesting a claim of ownership.

Non-Exclusive Use - Although it is conceded that the claimant engaged in some use of the property, it is alleged that others (usually the property owner) also used the property in a manner consistent with that of the landowner.

Insufficient Time - Even if various elements of adverse possession were met, it is alleged that the adverse possession didn't last for the full statutory period, or that the adverse possession was interrupted by a period of non-use.

\section{AdVERSE PoSSESSION In The UNITED StateS}

As suggested above, adverse possession in the United States is governed differently from state to state9, and the genesis of the same needs a slightly closer scrutiny, in order to understand the present day situation in in the American legal context. Early American law frequently imitated the English 1623 Statute of Limitations 10 with respect to the twenty-year statutory period and presently, adverse possession under American law has been influenced by this twenty-year lapse period. Many of the current day statutes deviate widely from the old English statute of limitations. (see adverse possession appendix)

On the other hand, there is a school of thought that contends that the foundations of America as a nation rest upon the principles of adverse possession. For example, a notable historian, Francis Jennings, states in his book - The

\footnotetext{
${ }^{6}$ Personal property, as per its general definition, can include any asset other than real estate. The differentiating factor between personal property and real estate is that personal property is movable.

${ }^{7}$ Section 2-403 of the Uniform Commercial Code ( The common law doctrine and Uniform Commercial Code are effective in all states except Louisiana, which applies somewhat similar rules based on its traditional civil law doctrines)

${ }^{8} \mathrm{http}: / /$ www.law.cornell.edu/uscode/text/43/1068

${ }^{9}$ Appendix I

${ }^{10} \mathrm{http}: / /$ andrewwarland.wordpress.com/2010/01/28/the-really-brief-history-of-the-origins-of-the-statute-oflimitations/
} 
Invasion of America-11 that the European settlers wanted to colonize the lands of one another, as well as lands of native people. He can be quoted directly as saying that - "At a time when chartered boundaries often overlapped and had rarely been surveyed, lords resorted to the ancient principle that actual possession, if maintained long enough, would eventually be recognized as legitimate jurisdiction." This notion is similar and precursor to the standard definition of adverse possession.

The above quotes and the interpretations lay the foundation for the ensuing discussion of adverse possession in the usurping of lands of the Native Americans.

\subsection{Appropriation of Native American Property/Lands}

$>$ In the past, there werefour main types of theories postulated to justify the seizing of the Native American lands:

$>$ The uncivilized and heathendisposition of the Native Americans as per the colonists12.

$>$ The nonexistence of farming of the lands by the Native Americans 13 .

$>$ The taking of lands as an act of war14.

While there have been several proponents and critics of the accuracy and fairness of theories mentioned above, history indicates that the above theories were indeed the driving factors behind the displacement of the Native Americans by the European settlers. During the era known to Americans as Manifest Destiny, the Native Americans were displaced to government assigned plots of land called reservations. Within these reservations the natives had certain autonomy and were free to govern themselves, as governmental organizations and the federal government, though the Bureau of Indian Affairs controlled and allocated federal funding to aid the reservations. However, as the population of the adjoining places in America grew, reservation lands, were taken, and the Native Americans were relocated to less populated locations, and usually areas perceived as having less economic value, and that would not be of significant interest to settlers. Over time, conditions on the reservations deteriorated and the population dropped drastically with poverty, unemployment and infant-mortality. Simultaneously, the federal government encouraged natives to leave the reservations, and most of them complied15.

Federal government policies, especially in the 19th- Century, encouraged the displacement of the Native Americans through various means, such as treaties 16 and acts promulgated specifically to that end. The removals were led by several treaties 17 , starting in 1795 , that slowly and steadily purchased most of the state from various tribes 18 . As an illustration, in the state of Indiana, the process of forced migrations of Native Americans started in the early 1830s, and was mostly finished by 1846 . The removal was part of a larger national Indian Removal Act19 passed by the United States Congress and was supported under the administration of President Andrew Jackson. When the removals started, most of the tribes such as the Shawnee and the Wea had left the state on their own, drifting into Canada and into Missouri. The only major tribes remaining were the Miami and the Potawatomi; both of which were already confined to reservation from previously signed treaties. Eventually, they conceded most of their lands to the United States through treaties20.

\subsection{Evolution of Native American Land Rights}

As American history progressed, the relationship between the Native Americans and the federal government kept fluctuating and this is reflected in the legislation that was enacted by the Congress to ostensibly safeguard the interests of the Native Americans and to integrate them into mainstream America. This course began with the

\footnotetext{
${ }^{11}$ http://uncpress.unc.edu/books/T-9074.html

${ }^{12}$ http://archive.org/stream/cu31924065777728/cu31924065777728_djvu.txt

${ }^{13}$ http://www.keithhunt.com/Reli.html

${ }^{14}$ http://www.encyclopediavirginia.org/_Declaration_Edward_Waterhouse_s

${ }^{15}$ http://www.digitalhistory.uh.edu/disp_textbook.cfm?smtID=2\&psid=3545

${ }^{16}$ https://history.state.gov/milestones/1830-1860/indian-treaties

${ }^{17}$ http://www.historyworld.net/wrldhis/PlainTextHistories.asp?ParagraphID=ncy

${ }^{18}$ http://www.surveyhistory.org/greenville_\&_grouseland_treaty_lines1.htm

${ }^{19}$ http://www.loc.gov/rr/program/bib/ourdocs/Indian.html

${ }^{20} 7$ Stat. 74, June 7, 1803, Treaty of Fort Wayne
} 
passage of the six rulings by Congress - together known as Indian Non-Intercourse Act21. The first Indian NonIntercourse act passed in 1790 prohibited all Indian land transactions that did not have the federal government's approval. This law enabled the federal government to deal with Indian tribes as foreign sovereigns (governments), having comprehensive authority over their lands and peoples. The federal government entered into treaties with tribes which after, the tribes usually gave up certain disputed lands in exchange for exclusive occupancy of treatyguaranteed lands. The Indian Non-Intercourse Act of 1790 was modified several times thereafter and the changes reflected the federal obligation to protecting tribes' treaty lands and the early federal avowal of legislative prevalence over transactions with tribes. The Indian Non-Intercourse Act declared illegal any "purchase, grant, lease, or other conveyance of lands" from any Indian tribe or nation unless the transaction was properly approved by the United States. The same policy has been reiterated and enhanced in statutes governing leasing and permitting of Indian lands, and is a pivotal element of Indian lands management policy in the current era. For example, the Passamaquoddy Indians claimed much of northern Maine under provisions of 1790 Act. This claim was settled in 1980, when the tribe voted 2-1 for a pact that provided 300,000 acres of land plus $\$ 81.5$ million22.The Passamaquoddy tribe had asked the federal government to file a lawsuit against Maine on the tribe's behalf, alleging that Maine had unfairly divested the Passamaquoddy tribe of most of its lands in a 1794 treaty between the state and the tribe. The federal government refused to act on behalf of the Passamaquoddy tribe because they were not a federally recognized Indian tribe, which implied that the United States had no "trust relationship" with the Passamaquoddy tribe and, therefore, should play no role in the their dispute with Maine. The Passamaquoddy tribe, however, argued in a lawsuit against the Secretary of the Interior and the Attorney General of the United States in district court and supported its claim of a trust relationship on the Non-Intercourse Act, enacted in its original form by the First Congress in 1790 to protect the lands of "any . . . tribe of Indians." The district court ruled that the unlimited reference to "any . . . tribe" must be read to include the Passamaquoddy tribe as well as tribes specially recognized under separate federal treaties, agreements or statutes. There were appeals made by the defendants, i.e., federal officials and state of Maine, but the appellate court agreed with the rulings of the district court and delivered a similar judgment in 1973. Thereafter, protracted negotiations and discussions went on among the federal government, state of Maine, and Passamaquoddy tribe for the next seven years and finally, the issue was settled with cash and land compensation.

The Indian Reorganization Act of 193423(This ended the apportioning of Native American lands under Dawes General Allotment Act of 188724), the Termination of Reservations Act of 195325 and the Indian Selfdetermination Act of 197526 are important legislations that conferred certain rights and privileges on Native Americans by enabling them to manage their own lands and administer themselves.

\section{Current Situation - Restitution And Contention}

Since the Native Americans had been reduced to a nomadic status, the federal government strived to uplift their socio-economic status. Native Americans gradually attained a unique status in which their lands were within the protection of the federal government, so that adverse possession could not deprive the Indian tribes of such land. The fundamental principle behind this theory stems from the Trade and Intercourse Act of 1790.This Act established a relationship of trust between the Native Americans and the Federal Government, and the United States had an affirmative duty on behalf of the Native Americans to protect them against transgressions or usurping of properties. The underlying dictum is that federal government, state governments or Indian tribes, do not lose land title by adverse possession and that legislative powers are not weakened because a government does not choose to exercise them. The United States is not prohibited from protecting its property interests by state limitation periods and since the Native Americans are regarded as wards of the federal government, this same non-application of statutes of limitations has often been extended to them27. Thus, the Native American tribes lands, by virtue of being treated at par with federal property cannot be seized under common law or state legislations governing adverse possession.

\footnotetext{
${ }^{21} 25$ USCS $\S 177$, Title 25. Indians Chapter 5. Protection of Indians

${ }^{22}$ Joint Tribal Council of the PassamaquoddyTribe v. Morton, 388 F. Supp. 649

${ }^{23} 25$ USCS § 476 , Title 25.

${ }^{24} 25$ USCS $\S 331$ et Seq.

${ }^{25} 25$ USCS § 891, 1953

${ }^{26} 25$ USCS $\S 450$ et Seq.

${ }^{27}$ U.S. Department of the Interior, Federal Indian Law 641 \& n.7 (1958)
} 
There are numerous cases which put forth the idea that the doctrine of adverse possession does not apply to the restricted Indian land. A few of them may be enumerated as follows:

\subsection{Oneida Indian Nation v. County of Oneida, 414 U.S. 661 (1974)28}

In Oneida Indian Nation v. County of Oneida, 414 U.S. 661, 39 L. Ed. 2d 73, 94 S. Ct. 772 (1974), the United States Supreme Court held that the Oneida Indian Nation had stated a federal cause of action cognizable under 28 U.S.C. $\S$ 1331 in claiming a right to possession of certain lands which it alleged had been ceded to the State of New York "without the consent of the United States and hence ineffective to terminate the Indians' right to possession under," the Non intercourse Act. The Act, 25 U.S.C. § 177, provides as follows:

"No purchase, grant, lease, or other conveyance of lands, or of any title or claim thereto, [**8] from any Indian nation or tribe of Indians shall be of any validity in law or equity, unless the same be made by treaty or convention entered into pursuant to the Constitution. Every person who, not being employed under the authority of the United States, attempts to negotiate such treaty or convention, directly or indirectly, or to treat with any such nation or tribe of Indians for the title or purchase or any lands by them held or claimed, is liable to a penalty of $\$ 1,000$. The agent of any State who may be present at any treaty held with Indians under the authority of the United States, in the presence and with the approbation of the commissioner of the United States appointed to hold the same, may, however, propose to, and adjust with, the Indians the compensation to be made for their claim to lands within such State, which shall be extinguished by treaty."

\subsection{United States v. 7,405.3 Acres of Land, 97 F.2d 417 (4th Cir. 1938)}

The case was based on a controversy over ownership of a parcel of land, which was claimed by both the United States as trustee for the Eastern Band of Cherokee Indians and by a North Carolina power company. The appeal court determined that title could not be taken from the government by contract, adverse possession or otherwise without its consent. The court determined that adverse possession did not divest the title help for the Indians, and title was in the United States as trustee for the Indians.

\subsection{United States, as guardian of the Hualapai Indians of Arizona, v. Santa Fe Pacific Railroad Co29}

Petitioner United States, in its own right and as guardian of the Indians of the Walapai tribe, sought review of a judgment of the Circuit Court of Appeals for the Ninth Circuit that affirmed the district court's grant of respondent railroad company's motion to dismiss. The United States sought to enjoin the railroad company from interfering with the Indians' possession and occupancy of certain land in northwestern Arizona. The Court affirmed the judgment of the lower court as modified. An accounting respecting such lands in the reservation which could be proved to have been occupied by the Walapais from time immemorial was ordered. To the extent that the decree below precluded such proof and accounting, it was to be modified.

\subsection{Burt J. Volvo et al., Plaintiffs, v. Seneca Nation of Indians et al., Defendants.30}

The homeowners leased land from defendant marina, which owned and operated land allocated to it by the Indian Nation. The homeowners began to build a home on the tribal property. They were charged with trespass by Indian authorities, because of an ongoing boundary line dispute over the land owned by the marina in the Indian Court. The court held that the doctrine of sovereign immunity compelled the dismissal of the action against the Indian Nation and its authorities. Under N.Y. Indian Law § 5, a recognized Indian tribe was not subject to state court jurisdiction simply because the underlying commercial transaction originally involved Indian and non-Indian individuals, only later to encompass the Indian Nation in a land dispute between the Indian Nation, one of its members, and the homeowners. An Indian tribe could not sue or be sued in state court without its consent or without express statutory authority. 25 U.S.C.S. $\S \S 232,233$ did not confer state jurisdiction over the tribes themselves or waive tribal sovereign immunity. The court did not have jurisdiction to determine whether the marina had a claim of adverse possession independent of the Indian allotment. The court granted the Indian Nation's motion for summary judgment and dismissed the complaint.

\footnotetext{
${ }^{28} 414$ U.S. 661,1974

${ }^{29} 314$ U.S. 339,1941

${ }^{30} 650$ N.Y.S.2d 937, 1996
} 


\section{EXCEPTION SCENARIOS}

While the above cases depict that the rights of Native Americans are by and large upheld in line with federal laws, the anomalies countered by the Native Americans in current times, and the consequences of the litigations also warrant a general discussion. The important point to remember is that the doctrine of adverse possession does apply to real property that Native American tribes hold in fee31.Another instance was in the case of South Dakota v. United States Department of Interior; the court overruled a 60 year-old statute, the Indian Reorganization Act, which authorized Native American trust acquisition32. The most surprising cases are when attempts are still made to displace Native American tribes because of pressing commercial or political reasons 33 .

There are numerous instances in recent past, where the Native American tribes have been entangled in lawsuits to claim the land that is said to be lawfully their own. One prominent case is that of the Miami Tribe claiming back vast swathes of land in Illinois34. The Miami Tribe was attempting to claim 2.6 million acres covering parts of 15 different in southeastern Illinois. Another situation was when direct descendants of the Ottawa's attempted to claim back 1,280 acres of state park and private farmland in DeKalb County. Both the Miami and Ottawa tribes had indicated their concern in reclaiming the land for "economic development" purposes and to right some of the injustices created by greed, manifest destiny and discrimination. However, the state officials who conducted discussions with the tribes suggested that "economic development" would mean only one thing: land-based casinos. As this continued, the tribes said they hoped to settle with the state for smaller amounts of comparable land and cash before the matter were to go to the courts and that gaming might be an option. In regards to the Miami Tribe, Illinois officials had discussed the possibility of developing legislation to establish insurance for landowners against Native American tribal claims and even asked Congress to develop similar federal legislation. A judgment was made against the Miami Tribe which resulted in a decision and they decided to drop the suit35. On May 9, 2002, Illinois State Representative Tim Johnson sponsored a bill to enable the Miami Tribe to take legal action against the federal government for land claims, instead of individual landowners 36 .

Instances such as these are indicative of the fact that Congress has demonstrated concern with providing compensation to Native American tribes for lands taken or title extinguished, compared to securing the return of land to the Native American tribes. There are arguments on both the sides of the issue. The general residents and state governments on those lands are granted sympathy and credibility on the grounds that two wrongs cannot make a right. The idea that displacing individuals who have been residing on those lands for a period of 20-60 years and ruling in favor of those who have likely never set foot on the land is a repetition of how the situation arose to begin with. This shows a situation in which the elements of adverse possession can be seen taking effect.

In the beginning of 2014, a similar situation arose in which the state of Wyoming found itself bracing against the Environmental Protection Agency (EPA) in an attempt keep hold of land with the risk of a large tract of it being given to Native American tribes37. Currently, the EPA is evaluating the requests of state authorities while taking into account as proliferation of casinos, law and order issues and depriving of taxes to the state government.

\section{Conclusion}

The doctrine of adverse possession does not apply to the ownership of government properties, which encompasses lands owned by Native American tribes. Many of the lands that are currently owned by Native American tribes were land grants. As Native Americans were forced to relocate, some of these original land grants were never taken back by treaty, and the legal documentation of the tribe's ownership are still intact. Currently, some lands that were originally land grants to Native American tribes have been developed by individuals, businesses, and government and these lands still belong to Native American tribes. These individuals, businesses, and governments are all at risk of having the ownership of the land brought into question in a court of law. The argument of adverse possession

\footnotetext{
${ }^{31}$ http://www.leagle.com/decision/19661202258FSupp944_11041.xml/UNITED\%20STATES\%20v.\%20WILCOX

${ }^{32} \mathrm{http}: / /$ www.leagle.com/decision/20041249314FSupp2d935_11159.xml/SOUTH\%2ODAKOTA\%20v.\%20U.S.\%20DE PT.\%200F\%20INTERIOR

${ }^{33}$ https://www.greenleft.org.au/node/14879

${ }^{34} \mathrm{http}: / /$ www.ao.uiuc.edu/courses/aiiopcmpss/MiamiCase/mediacase/1998Sept18.htm

${ }^{35} \mathrm{http}: / /$ www.ao.uiuc.edu/courses/aiiopcmpss/MiamiCase/mediacase/2001,\%20June\%2015.htm

${ }^{36} \mathrm{http}: / /$ www.ao.uiuc.edu/courses/aiiopcmpss/MiamiCase/index.htm

${ }^{37} \mathrm{http}: / /$ www.foxnews.com/politics/2014/02/12/wyoming-officials-prepare-for-court-fight-against-epa-rulingthat-gave-land-to/
} 
will not prevail for those contending that since they have possessed the land for a number of years, that they now have title to the land, since the doctrine of adverse possession cannot be used against government. The tribes with the correct documentation can fight for monetary for the land or even repossess the lands.

\begin{tabular}{|l|l|l|l|}
\hline State & Time for Occupation & \multicolumn{2}{|c|}{ State } \\
\hline Alabama & $20^{1}$ & Montana & $5^{7}$ \\
\hline Alaska & $10^{2}$ & Nebraska & 10 \\
\hline Arizona & $10^{3}$ & Nevada & $5^{16}$ \\
\hline Arkansas & $7^{4}$ & NewHampshire & 20 \\
\hline California & $5^{4}$ & New Jersey & $30^{17}$ \\
\hline Colorado & $18^{6}$ & New Mexico & $10^{7}$ \\
\hline Connecticut & 15 & New York & $10^{18}$ \\
\hline Delaware & 20 & North Carolina & $20^{19}$ \\
\hline District ofColumbia & 15 & North Dakota & $20^{20}$ \\
\hline Florida & $7^{7}$ & Ohio & 21 \\
\hline Georgia & $20^{8}$ & Oklahoma & 15 \\
\hline Hawaii & $20^{9}$ & Oregon & 10 \\
\hline Idaho & $20^{5}$ & Pennsylvania & 21 \\
\hline Illinois & $20^{10}$ & Rhode Island & 10 \\
\hline Indiana & $10^{11}$ & South Carolina & $10^{18}$ \\
\hline Iowa & 10 & South Dakota & $20^{20}$ \\
\hline Kansas & 15 & Tennessee & 7 \\
\hline Kentucky & $15^{12}$ & Texas & $10^{21}$ \\
\hline Louisiana & $10^{13}$ & Utah & $7^{7}$ \\
\hline Maine & 20 & Vermont & 15 \\
\hline Maryland & 20 & Virginia & $15^{18}$ \\
\hline Massachusetts & 20 & Washington & $7^{7}$ \\
\hline Michigan & 15 & West Virginia & 10 \\
\hline Minnesota & $15^{14}$ & Wisconsin & $20^{22}$ \\
\hline Mississippi & $10^{15}$ & Wyoming & 10 \\
\hline Missouri & 10 & & \\
\hline
\end{tabular}

1. 10 years under color of tile and payment of taxes

2. 7 years with color of title; 10 years good faith, mistaken belief

3. 10 years: no more than 160 acres

4. 7 year for unimproved and unenclosed land held under color of title; 15 years

5. Payment of taxes

6. 40 years with 20 years of occupation through tenants.

7. Color of title and payment of taxes

8. 7 years under color of title

9. Real property must be five acres or less to qualify

10. 7 years under color of title and payment of taxes

11. Claimant must pay and discharge all taxes reasonably believed to be due in good faith

12. 7 years under color of title

13. Good Faith

14. Payment of taxes for 5 consecutive years

15. 3 years if title from tax sale

16. With color of title and payment of taxes, 2 years for recovery of mining claims

17. Color of title, 60 years for woodlands and uncultivated tracts

18. Color of title

19. Can't eject after 5 years

20. Under color of title, 10 years for payment of taxes/color of title

21. 5 years color payment of taxes, 3 years color of title

22. 40 years with 20 years of occupation through tenants 